\title{
The Determinants of Economic Resilience. The Case of Eastern European Regions
}

\author{
Florin Oprea ${ }^{1}$, Mihaela Onofrei ${ }^{1}$, Dan Lupu ${ }^{1, *}$, Georgeta Vintila ${ }^{2}$ and Gigel Paraschiv ${ }^{3}$ \\ 1 Department of Finance, Money and Public Administration, Alexandru Ioan Cuza University of Iasi, \\ 700506 Iasi, Romania; foprea@uaic.ro (F.O.); onofrei@uaic.ro (M.O.) \\ 2 Department of Finance, The Bucharest University of Economic Studies, 6 Piata Romana, \\ 010374 Bucharest, Romania; georgeta.vintila@fin.ase.ro \\ 3 Faculty of Biotechnical Systems Engineering, Polytechnic University, 060042 Bucharest, Romania; \\ paraschiv2005@yahoo.com \\ * Correspondence: dan.lupu@uaic.ro; Tel.: +40-742-074-705
}

Received: 31 March 2020; Accepted: 18 May 2020; Published: 21 May 2020

\begin{abstract}
The economic crisis of 2008 strongly affected European countries, many of them slipping into a recession whose depth and manifestation differed substantially from country to country and from region to region. In this context, economists revived the concept of economic resilience of states and regions and focused on identifying and explaining its determinants. The literature investigates ways to enhance economic resilience through appropriate public policies, but the studies conducted so far have several limitations. In order to contribute to this goal, this article analyzes the economic resilience of the regions of seven Eastern European countries (Bulgaria, Hungary, Croatia, Czech Republic, Romania, Slovakia and Slovenia) and its main determinant factors. The results show that, in terms of resistance, Bulgaria, Slovenia and their regions behaved best, while Croatia, Czech Republic, Hungary, Romania and Slovakia (including regions) had a negative evolution. In terms of recovery Bulgaria (and 4 regions out of 6), Romania (5 out of 8 regions) and Slovakia (4 of 4 regions) performed better than the other Eastern countries. The determining factors of resilience for the studied regions concern the size of the manufacturing sector, the services and public administration, entrepreneurship and the human capital represented by tertiary education; agriculture and urban population have no significant influence on regional resilience. We adopt an econometric approach in this study, using the quantile regression for the analysis. Based on these empirical evidences, appropriate proposals have been formulated, useful to both field theorists and practitioners in public policy.
\end{abstract}

Keywords: Eastern European regions; resistance; recovery; quantile regression; 2008-2009 financial crisis

\section{Introduction}

The financial crisis of 2008 hit Europe but manifested itself differently in the states of the Union, some of them being more severely affected and others less so [1]. In addition, at the level of the European NUTS2, (he Nomenclature of territorial units for statistics, abbreviated NUTS (from the French version Nomenclature des Unités territoriales statistiques) is a geographical nomenclature subdividing the economic territory of the European Union (EU) into regions at three different levels (NUTS 1,2,3) the response to the economic crisis was different, between the regions of different states, and sometimes even between regions of the same state [2]. The causes of the different responses to the crisis of 2008 are thought to include, among others, economic development levels that were not homogeneous in the previous period [3], although at the EU level it was tried, through the common policies, to achieve a convergence and harmonization between states and regions [4]. EU Structural Funds have helped reduce the disparities between Eastern European states and regions compared with Western ones at the level of GDP per capita, but economic development remains uneven [5]. 
Under the conditions of the severe economic crisis of 2008, a new concept-the concept of resilience-was developed, in order to better understand how to resist and help state and regional economies recover from recessionary shocks. Regional resilience is defined as the ability of a regional economy to cope and recover from various shocks, of economic/political/environmental nature, either by returning to the old path of development or moving on to a new, better one [6]. The concept of resilience, initially used in natural sciences, medicine and engineering to designate shock system resistance and the ability to return to equilibrium, was subsequently taken over and adapted to the economy [7]. In the economy, resilience is considered to be composed of the following elements: resistance (the ability of an economy to cope with shocks); absorption (the ability of an economy to take over a shock), recovery (the ability of an economy to return to its former state) and reorientation (if any, the ability of an economy to structurally change and restore an equilibrium higher than that of the initial state) [8].

Regional economic resilience is the ability of a state's regions to cope with changes in the nature of shocks and disruptions, regardless of their nature (economic, disasters, environment, health), and to use these events to continue their development. Regional economic vulnerability refers to the way in which the economy of a region reacts negatively to shocks. It is a complex and dynamic concept that includes a wide range of potentially disruptive factors: economic, environmental, social.

Regional economic recovery is another methodological concept used in close connection with economic resilience; it shows the capacity of a region to recover/adapt to changes of the nature of external shocks in a shorter period, less harmful to economic values (GDP, employment) and prior to the manifestation of negative phenomena.

The present paper aims to study the economic resilience of seven Eastern European states, among which Bulgaria, Hungary and Romania, and their component regions during the period of the financial crisis of 2008-2009, as well as their subsequent economic recovery, until 2014. The choice of Eastern European countries was made based on similarities between them and the regions; other important aspect were their communist past and their access to the EU in 2004-2007, being recognized that path-dependence can influence the resilience of a system. At the same time, the choice was based on the common economic characteristics of the population and of education, which are both structural.

The seven countries studied are economically similar, Slovenia being the most developed, followed by Czech Republic and Hungary. Romania and Bulgaria are the last ones. The NUTS2 regional division is quite similar: Bulgaria has six regions, Croatia two, Czech Republic eight, Hungary eight, Romania eight, Slovakia four and Slovenia two; in 2008, five regions in Bulgaria, six in Romania and only one in Hungary were the poorest 20 regions in the EU, and in 2014 there was an improvement: only four regions in Bulgaria and five in Romania were in the same top [9-14]. The most developed regions in 2008 were Praha, Bratislavský kraj, Budapest, Zahodna Slovenija and Bucharest-Ilfov, and in 2014, this top remained unchanged. The poorest regions in 2008 were Severozapaden, Yuzhen tsentralen, Severen tsentralen, Yugoiztochen and Nord-Est; likewise, in 2014, the top remained unchanged.

The structural factors that influence the resilience of the regions are among the most diverse: the structure of the economic activity, and especially the industrial heritage [10]; the structure of exports, and in particular the access to strong foreign markets [11]; the quantity of natural, physical and human resources [12]. In particular, the literature shows that the narrow specialization in certain fields of activity negatively influences the resilience of regions and states [13]. The measurement of economic resilience is usually done with the help of macroeconomic indicators, GDP or employment changes [14]. In this study, the resilience measurement will be done taking into account GDP changes for 2008 (the year before the crisis) and 2014 (the year of the crisis exit).

Starting from the asymmetric impact of the recessionary shocks at the regional level, the present study aims to analyze the influence of the economic activity structure on the resilience of the regions of seven Eastern European states (Bulgaria, Croatia, Czech Republic, Hungary, Romania, Slovakia and Slovenia) during the period 2007-2014 of the economic crisis. The aim of our research paper 
is to measure the resilience of the regions of the seven Eastern European states and to identify the determinants of this phenomenon.

The novelty of this research consists in the following aspects: (a) the choice of the seven Eastern European states, little studied in the literature; (b) the study of the resilience of the 38 component regions of the mentioned states, a study which has not been carried out so far; (c) the analysis of the impact of the economic structure on regional resilience.

The paper will contribute through three directions to the literature on regional economic resilience: first, it separately calculates coefficients for resilience on the two phenomena-resistance and recovery; secondly, it analyzes ex ante and ex post the determinants of resilience; and finally, it calculates the influence of these factors on the resilience of the two components-resistance and recovery.

To achieve the purpose of this study, after the introductory section, Section 2 presents the main ideas developed about regional resilience in the extant literature. Section 3 describes the methodology used to reach the results, Section 4 shows the main results obtained from the analysis and the last section presents the main conclusions of the study.

\section{Literature Review}

Periodically, the economies of the states are hit by shocks. The effects of these phenomena are different between states and especially between regions, with great differences being observed even within the same state [15]. The literature deals with regional economic resilience, raising legitimate questions: why are some regions affected more by a crisis while others are not? What are the mechanisms that lead some regions to recover faster than others? [16] Although it is used in many areas, the concept of resilience does not have a clear and unanimously accepted definition, but it starts from the broad concept of a system's ability to return to its initial state after a disruptive shock $[17,18]$.

The term of resilience in the economic environment was introduces by [19], studying the economic effects of earthquakes on local communities and shows that this phenomenon represents the process by which a community responds and adapts to external shocks. The pioneers in the development of the concept of economic resilience [20], using a series of macroeconomic indicators: fiscal deficit, inflation, unemployment, good governance; this study classifies the countries, according to their own resilience index, into four categories: best case, worst case, self-made and prodigal sound. The concept of resilience used by [21] at the level of UK regions, adapting the concept of balance and introducing new evolutionary concepts, the regional economies being in a continuous process of change and adaptation. The analysis of a number of US cities by [22] hit by shocks and concludes that there are several common factors, which influence resilience: infrastructure, innovation, skilled workforce, adequate financial system.

The regional development for the EU Member States was studied by [23] for the period 1995-2009 and concludes that the determinants of resilience are extremely varied: infrastructure, human capital, innovation, and urban agglomeration, ultimately leading to strong variations between regions.

The UK regions was analyzed by the [24] for the period 1970-2010 and concludes that resilience is a dynamic process consisting of several stages: resistance, recovery, renewal, and reorientation, with different repercussions on companies, individuals, and institutions. The study of the unemployment phenomenon during four crises made by [25], for the UK regions and for the period 1970-2012 and show that the structure of the economic activities does not have a decisive influence on the phenomenon.

The studies presented above focus mainly on descriptive analyses either of some regions or on analyses limited to regions of Western European states. Eastern European countries and their regions have been extremely poorly analyzed. Although there are several studies, they mainly refer to the comparative analysis of all NUTS 2 EU regions.

The European NUTS 2 regions from the point of view of resilience to unemployment were analyzed by [26], for the period 2002-2013, and shows that there are significant differences between the North-Central and Southern regions, mainly determined by the presence of the manufacturing sector, education and migration flows. 
The Regional Competitiveness Index (RCI) was examined by [27], with its own index, similar to the one promoted by the World Bank, and shows that compared to the other two calculations in 2010 and 2013, a number of regions (in France, Germany and Sweden) improved values; those from the Southeast of the continent (Greece, Italy and Portugal) have worsened them; and for those from the East of the continent, the values are similar.

The regions of the EU were studied by [28], proposing a composite index based on five components: community, human capital, labor market, economic performance and innovation, and shows that the resilience process is a long one, in which all social actors must participate.

\section{Methodology}

The literature has not yet reached a consensus regarding the construction of an indicator to measure regional resilience, although a significant number of studies have tried to do so. In this study, we consider that regional economic resilience is a process composed of two elements: resistance (the ability of a region to cope with a shock) and recovery (the ability of a region to recover as quickly as possible from a shock). The extant literature uses two macroeconomic indicators for the calculation of resilience: GDP and unemployment [29-31]; in this study, we will use GDP as a calculation indicator, because it better reflects the economic impact of shocks, and because unemployment is dependent on GDP.

Another reason for choosing GDP is that the analyzed period is divided into two components: resistance and recovery; GDP reacts faster and more convincingly to shocks, while unemployment has a longer response period to economic shocks. In fact, for the analyzed period, in the respective regions, the economic fall corresponds to the world economic crisis (2008-2009). The same happens in the case of economic recovery, which follows the same global trend, with the regions recovering in 2013-2014 (the last year of the analysis). Unemployment followed a different trajectory for the analyzed regions: into the period of resistance it was gradually decreasing until 2011-2012, and the recovery for some regions lasted until 2017.

The methodology chosen for the analysis in the present study consists of two steps: the first step is to build the resistance index and the recovery index as dependent variables; the second step is a regression analysis, OLS (ordinary least squares (OLS) is a type of linear least squares method for estimating the unknown parameters in a linear regression model) type and quantiles.

However, starting from the established studies in the field, the methodology we have chosen implies the construction of the following resilience index of the studied regions, separately for each of the two periods (first period, resistance, and second period, recovery). The writing of Equations (1) and (2) is based on the established models, used in the literature, and especially in $[1,8,12]$.

$$
\begin{aligned}
& \text { Resistance }=\left[\left(E c R_{t}-E c R_{t-1}\right) / E c R_{t-1}-\left(E c E U_{t}-E c E U_{t-1}\right) / E c E U_{t-1}\right] /\left(E c E U_{t}-E c E U_{t-1}\right) / E c E U_{t-1} \\
& \text { Recovery }=\left[\left(E c R_{t}-E c R_{t-1}\right) / E c R_{t-1}-\left(E c E U_{t}-E c E U_{t-1}\right) / E c E U_{t-1}\right] /\left(E c E U_{t}-E c E U_{t-1}\right) / E c E U_{t-1}
\end{aligned}
$$

where $E c R_{t}$ is the GDP at the regional level (in millions of euros); $E c E U_{t}$ is the relative measure of GDP change to compare the regions' performance with that of the EU27 level (in millions of euros); $t-1$ is the initial period of the analysis (year: 2008 for the resistance index and 2009 for the recovery index); $t$ is the end period of the analysis (year: 2009 for the resistance index and 2011 (Bulgaria) and 2014 (Hungary and Romania) for the recovery index). The source of the data used in the paper is Eurostat, and GDP, agriculture, manufacturing, IT and services and gross fixed capital formation (gross fixed capital formation for physical capital) are measured in euros (entrepreneurship), tertiary education and urban population are measured in percentage of the population. Subsequently, in the analysis, these data are used by transformation according to Equations (1) and (2).

The construction of this resilience index was carried out taking into account different studies [32]. The resilient regions are those where the change of GDP is greater than the change of GDP of the $\mathrm{EU}$ (resistance $>0$ and recovery $>0$ ), and the non-resilient regions are the ones where the GDP 
change is smaller than the EU's GDP change (resistance $<0$ and recovery $<0$ ). In order to ensure the comparability of the data, the EU's GDP change was taken into account, a factor to be reported by all the analyzed regions.

The second step of the analysis is given by investigating the influence of the determinants (agriculture (covers the income of all units involved in agricultural production, NACE2 code A), manufacturing (includes the physical or chemical transformation of materials, substances, or components into new products, NACE2 code C), services (includes activities such as wholesale and retail trade, transport, accommodation and food service activities, information and communication, NACE2 codes G-J), public administration (includes activities of a governmental nature, NACE2 codes $\mathrm{O}-\mathrm{Q}$ ), entrepreneurship (population of active enterprises), tertiary education (population by educational attainment level: the highest level of education successfully completed by the individuals of a given population), physical capital (as gross capital formation) and urban population (percentage of population living in urban areas on the previously calculated dependent variables: resistance index and recovery index).

Agriculture occupies an extremely important place in the economy of these regions, much higher than that occupied in European regions (the average in Bulgaria exceeds 15\%, in Hungary $11 \%$ and in Romania $14 \%$, with a minimum of $2 \%$ in the Budapest region and a maximum of $24.5 \%$ in Yuzhen tsentralen); manufacturing exceeds by far the European average (the average in Bulgaria is $18 \%$, in Hungary $16 \%$ and in Romania $14 \%$, with a minimum of $7.8 \%$ in Dél-Alföld and a maximum of $33.62 \%$ in Yugozapaden). The public administration's contribution to the GDP is very different from that of the EU (the average in Bulgaria is $21 \%$, in Hungary $17 \%$ and in Romania $12 \%$, with a minimum of $6.1 \%$ in Közép-Dunántúl and a maximum of $41.95 \%$ in Yugozapaden).

The basic OLS regression is as follows:

$$
\begin{aligned}
& \text { Resistance }_{t}=\alpha_{1} \text { Agriculture }_{t}+\alpha_{2} \text { Manufacturing }_{t}+\alpha_{3} \text { Services }_{t}+\alpha_{4} \text { Public Administration }_{t} \\
& +\alpha_{5} \text { Entrepreneurship }_{t}+\alpha_{6} \text { Tertiaryeducation }_{t}+\alpha_{7} \text { Physicalcapital }_{t}+\alpha_{8} U R B_{t}+\varepsilon_{t} \\
& \text { Recovery }_{t}=\beta_{1} \text { Agriculture }_{t}+\beta_{2} \text { Manufacturing }_{t}+\beta_{3} \text { Services }_{t} \\
& +\beta_{4} \text { PublicAdministration } t+\beta_{5} \text { Entrepreneurship }_{t}+\beta_{6} \text { Tertiaryeducation }_{t} \\
& +\beta_{7} \text { Physical capitalt }+\beta_{8} U R B_{t}+\varepsilon_{t}
\end{aligned}
$$

The quantile regression can be expressed as follows:

$$
\begin{gathered}
\operatorname{Resistance}_{t}(\mu)=\alpha_{1} \text { Agriculture }_{t}\left(\varepsilon_{t}\right)+\alpha_{2} \text { Manufacturing }_{t}\left(\varepsilon_{t}\right)+\alpha_{3} \text { Services }_{t}\left(\varepsilon_{t}\right) \\
+\alpha_{4} \text { PublicAdministration }_{t}\left(\varepsilon_{t}\right)+\alpha_{5} \text { Entrepreneurship }_{t}\left(\varepsilon_{t}\right)+\alpha_{6} \text { Tertiaryeducation }_{t}\left(\varepsilon_{t}\right) \\
+\alpha_{7} \text { Physicalcapital }_{t}\left(\varepsilon_{t}\right)+\alpha_{8} U R B_{t}
\end{gathered}
$$

where Resistance $(\mu)$ and Recovery $f_{t}(\mu)$ are the quartile conditional distribution $(\mu)$. To use quantile regression, suppose that there is a uniform conditional distribution for Agriculture $_{t}(\varepsilon t)$, Manufacturing $t_{t}$ $(\varepsilon t)$, Services $_{t}(\varepsilon t)$, PublicAdministration $_{t}(\varepsilon t)$, Entrepreneurship $_{t}(\varepsilon t)$, Tertiaryeducation $_{t}(\varepsilon t)$, Physicalcapital $_{t}$ $(\varepsilon t), \operatorname{Urban}_{t}(\varepsilon t)$.

\section{Results}

The financial crisis has influenced regions and states in Eastern Europe differently. Table 1 presents the evolution of GDP in the seven analyzed states (Bulgaria, Croatia, Czech Republic, Hungary, Romania, Slovakia and Romania) during the financial crisis period (2007-2014). As can be seen, the year 2008 represents the maximum point before the crisis for all the studied entities: EU, Bulgaria, Croatia, Czech Republic, Hungary, Romania, Slovakia and Slovenia, and their regions. The year 2009 
represents the minimum moment of the crisis for Croatia, Czech Republic, Hungary, Romania and Slovakia, and their regions. Bulgaria has undergone an atypical evolution: at the level of the whole country, the decrease was manifested only in 2009, and at the level of the regions until 2010; later, the recovery period is shorter only until 2011. As for the other six Eastern states (Croatia, Czech Republic, Hungary, Romania and Slovakia), although they have larger economies, the recovery period was longer: 2009-2014; a similar pattern was followed by their component regions.

Table 1. GDP evolution in the 7 East European countries and their regions in 2007-2014 (billions of euros).

\begin{tabular}{cccccccc}
\hline GDP & $\mathbf{2 0 0 8}$ & $\mathbf{2 0 0 9}$ & $\mathbf{2 0 1 4}$ & GDP & $\mathbf{2 0 0 8}$ & $\mathbf{2 0 0 9}$ & $\mathbf{2 0 1 4}$ \\
\hline European Union & 13082 & 12324 & 14091 & Czech Republic & 161.31 & 148.68 & 161.43 \\
Bulgaria & 37.21 & 37.20 & 42.87 & Praha & 41.26 & 37.94 & 39.93 \\
Severozapaden & 2.93 & 2.83 & 3.04 & Strední Cechy & 17.64 & 15.91 & 17.87 \\
Severen tsentralen & 3.12 & 3.06 & 3.54 & Jihozápad & 15.77 & 15.04 & 16.17 \\
Severoiztochen & 4.18 & 4.02 & 4.76 & Severozápad & 13.65 & 12.92 & 13.24 \\
Yugoiztochen & 4.52 & 4.59 & 5.43 & Severovýchod & 18.88 & 17.40 & 18.85 \\
Yugozapaden & 17.20 & 17.58 & 20.25 & Jihovýchod & 22.86 & 21.18 & 23.86 \\
Yuzhen tsentralen & 5.24 & 5.29 & 5.83 & Strední Morava & 15.04 & 13.88 & 15.22 \\
Hungary & 108.21 & 94.38 & 105.90 & Moravskoslezsko & 16.18 & 14.36 & 16.25 \\
Budapest & 40.26 & 36.58 & 39.13 & Croatia & 47.99 & 45.06 & 43.94 \\
Pest & 11.40 & 9.89 & 10.97 & Jadranska Hrvatska & 15.38 & 14.37 & 13.95 \\
Közép-Dunántúl & 10.83 & 8.72 & 10.34 & Kontinentalna Hrvatska & 32.61 & 30.68 & 29.98 \\
Nyugat-Dunántúl & 10.74 & 9.01 & 11.19 & Slovenia & 37.92 & 36.25 & 36.25 \\
Dél-Dunántúl & 6.97 & 6.10 & 6.46 & Vzhodna Slovenija & 16.81 & 15.90 & 15.97 \\
Észak-Magyarország & 8.08 & 6.75 & 7.87 & Zahodna Slovenija & 21.10 & 20.35 & 20.27 \\
Észak-Alföld & 10.14 & 8.95 & 10.19 & Slovakia & 66.09 & 64.09 & 73.48 \\
Dél-Alföld & 9.76 & 8.34 & 9.71 & Bratislavský kraj & 17.71 & 18.39 & 20.37 \\
Romania & 146.59 & 125.21 & 150.45 & Západné Slovensko & 21.60 & 20.31 & 23.68 \\
Nord-Vest & 16.70 & 14.46 & 17.25 & Stredné Slovensko & 13.27 & 12.69 & 14.42 \\
Centru & 16.29 & 14.07 & 16.49 & Východné Slovensko & 13.49 & 12.68 & 14.99 \\
Nord-Est & 15.52 & 13.44 & 15.21 & & & &
\end{tabular}

Source: Eurostat.

Table 2 presents the resistance and recovery indices, calculated for the regions analyzed according to Equations (1) and (2). For Bulgaria and Slovenia, as well as for their regions, the resistance index is calculated for the period 2008-2010; for the other countries (Czech Republic, Croatia, Hungary, Romania and Slovakia) and their regions, the resistance index is calculated for the period 2008-2009. For the recovery index, the calculation is made according to the period needed to return to the situation in 2008. For Bulgaria and Slovenia and their regions, the economic recovery period is shorter: 2009-2011; for Hungary and Romania, the recovery period is longer: 2009-2014. As can be seen from Table 2, Bulgaria and Slovenia and its regions performed even better than the EU for the resistance period (six Bulgarian regions and two Slovenian regions); on the other hand, the other Eastern countries and their regions (Croatia, two of two regions; Czech Republic, six of eight regions; Hungary, eight of eight regions; Romania, eight of eight regions; Slovakia, two of four regions) have evolved worse than the average of EU regions. For the recovery period, the Eastern countries and their regions recovered at the average of the EU regions: Bulgaria (had only two regions lower than the EU average); Croatia (two of two); Czech Republic (four of eight); Hungary (four of eight regions); Romania (three of eight regions); Slovakia (four of four) and Slovenia (zero of two). 
Table 2. Resistance and recovery index.

\begin{tabular}{cccccc}
\hline Regions & Resistance & Recovery & Regions & Resistance & Recovery \\
\hline Bulgaria & 1.084 & 0.021 & Czech Republic & -0.352 & -0.101 \\
Severozapaden & 0.366 & -0.466 & Praha & -0.386 & -0.451 \\
Severen tsentralen & 0.701 & 0.073 & Strední Cechy & -0.691 & 0.285 \\
Severoiztochen & 0.314 & 0.278 & Jihozápad & 0.206 & -0.212 \\
Yugoiztochen & 1.273 & 0.273 & Severozápad & 0.080 & -0.740 \\
Yugozapaden & 1.385 & 0.060 & Severovýchod & -0.357 & -0.121 \\
Yuzhen tsentralen & 1.181 & -0.290 & Jihovýchod & -0.266 & 0.321 \\
Hungary & -1.207 & -0.148 & Strední Morava & -0.335 & 0.010 \\
Budapest & -0.576 & -0.514 & Moravskoslezsko & -0.935 & 0.373 \\
Pest & -1.289 & -0.236 & Croatia & -0.055 & -1.261 \\
Közép-Dunántúl & -2.362 & 0.295 & Jadranska Hrvatska & -0.130 & -1.310 \\
Nyugat-Dunántúl & -1.777 & 0.689 & Kontinentalna Hrvatska & -0.020 & -1.237 \\
Dél-Dunántúl & -1.142 & -0.590 & Slovenia & 0.239 & -1.012 \\
Észak-Magyarország & -1.854 & 0.165 & Vzhodna Slovenija & 0.059 & -0.950 \\
Észak-Alföld & -1.019 & -0.040 & Zahodna Slovenija & 0.382 & -1.039 \\
Dél-Alföld & -1.512 & 0.146 & Slovakia & 0.476 & 0.533 \\
Romania & -1.518 & 0.406 & Bratislavský kraj & 1.667 & 0.124 \\
Nord-Vest & -1.309 & 0.343 & Západné Slovensko & -0.030 & 0.737 \\
Centru & -1.354 & 0.197 & Stredné Slovensko & 0.238 & 0.426 \\
Nord-Est & -1.311 & -0.084 & Východné Slovensko & -0.040 & 0.907 \\
Sud-Est & -1.182 & 0.876 & & & \\
Sud-Muntenia & -0.802 & 0.318 & & & \\
Bucuresti-Ilfov & -2.352 & 1.066 & & & \\
Sud-Vest Oltenia & -1.131 & -0.342 & -0.175 & & \\
Vest & -1.522 & - & & \\
& & & &
\end{tabular}

Source: own calculations.

In the following, we will analyze the influence of the determinants at the level of the regions for the seven Eastern European states. Our analysis starts with the three components: the structure of economic activities (agriculture, manufacturing, services, and public administration), human capital (population and level of education) and physical capital (gross fixed capital formation) [24-26].

The structure of the economic activities is considered an important factor that has influence on the regional economic resilience, by the fact that the regions that have an increased economic diversity can better cope with the economic shocks and recover in a shorter period [27,28]. The same Indicators were taken into account precisely in order to be able to analyze their influence in the two periods of time, resistance and recovery.

As can be seen from Table 3, the diversity of the economy has its mark on the resilience of the regions of the seven Eastern states. For the period of resistance, two economic activities have an influence on the indicator (manufacturing and public administration); instead, two do not influence economic resistance (agriculture and services). For the recovery period, the results are similar, but there is still a change: the place of manufacture is taken by the services sector; agriculture has no influence on the phenomenon of recovery, and the public administration retains its role. Regarding the influence of the sectors between the two periods, it is observed that for the period of resistance, the manufacturing sector has an important role (coefficient of 3.697) and that during the recovery period it will no longer play the same role. The services sector although initially had an influence detected by the regression; for the recovery period, the influence is positive (0.256); public administration shows a greater influence in the first period, of resistance (6.625) compared to the second period of recovery (2.774). Entrepreneurship has a positive and important influence in both periods, 3.401 in the first period, and 0.933 in the recovery period. 
Table 3. The determinants of resistance and recovery index (OLS and Quantile regression).

\begin{tabular}{|c|c|c|c|c|c|c|c|c|}
\hline \multirow[t]{3}{*}{ Variable } & \multicolumn{4}{|c|}{ Resistance } & \multicolumn{4}{|c|}{ Recovery } \\
\hline & \multirow[t]{2}{*}{$\begin{array}{c}\text { OLS } \\
\text { Estimates }\end{array}$} & \multicolumn{3}{|c|}{ Quantile Regression Estimates } & \multirow[t]{2}{*}{$\begin{array}{c}\text { OLS } \\
\text { Estimates }\end{array}$} & \multicolumn{3}{|c|}{ Quantile Regression Estimates } \\
\hline & & 0.25 & 0.50 & 0.75 & & 0.25 & 0.50 & 0.75 \\
\hline Agriculture & $\begin{array}{c}0.685 \\
(0.42 *)\end{array}$ & $\begin{array}{l}-0.039 \\
(0.97 *)\end{array}$ & $\begin{array}{l}1.417 \\
\left(0.40^{*}\right)\end{array}$ & $\begin{array}{l}-0.115 \\
\left(0.95^{*}\right)\end{array}$ & $\begin{array}{c}0.775 \\
\left(0.06^{*}\right)\end{array}$ & $\begin{array}{c}1.183 \\
\left(0.07^{*}\right)\end{array}$ & $\begin{array}{l}-1.460 \\
\left(0.19^{*}\right)\end{array}$ & $\begin{array}{l}-0.675 \\
\left(0.30^{*}\right)\end{array}$ \\
\hline Manufacturing & $\begin{array}{c}3.792 \\
(0.00 *)\end{array}$ & $\begin{array}{c}4.406 \\
\left(0.00^{* *}\right)\end{array}$ & $\begin{array}{l}-0.896 \\
\left(0.61^{*}\right)\end{array}$ & $\begin{array}{l}-1.878 \\
\left(0.47^{*}\right)\end{array}$ & $\begin{array}{c}1.529 \\
\left(0.64^{*}\right)\end{array}$ & $\begin{array}{c}0.803 \\
\left(0.03^{*}\right)\end{array}$ & $\begin{array}{c}1.999 \\
\left(0.47^{*}\right)\end{array}$ & $\begin{array}{l}-0.191 \\
\left(0.43^{*}\right)\end{array}$ \\
\hline Services & $\begin{array}{c}0.751 \\
\left(0.33^{*}\right)\end{array}$ & $\begin{array}{c}1.185 \\
\left(0.07^{*}\right)\end{array}$ & $\begin{array}{l}-0.069 \\
\left(0.94^{*}\right)\end{array}$ & $\begin{array}{c}0.588 \\
\left(0.54^{*}\right)\end{array}$ & $\begin{array}{c}0.256 \\
\left(0.04^{* * *}\right)\end{array}$ & $\begin{array}{c}0.205 \\
\left(0.04^{* * *}\right)\end{array}$ & $\begin{array}{c}0.019 \\
\left(0.97^{*}\right)\end{array}$ & $\begin{array}{c}0.031 \\
(0.79 *)\end{array}$ \\
\hline $\begin{array}{c}\text { Public } \\
\text { Administration }\end{array}$ & $\begin{array}{c}6.625 \\
(0.01 *)\end{array}$ & $\begin{array}{c}5.694 \\
\left(0.00^{*}\right)\end{array}$ & $\begin{array}{c}2.264 \\
\left(0.24^{*}\right)\end{array}$ & $\begin{array}{c}2.101 \\
\left(0.47^{*}\right)\end{array}$ & $\begin{array}{c}2.774 \\
\left(0.04^{*}\right)\end{array}$ & $\begin{array}{c}2.024 \\
\left(0.4^{* *}\right)\end{array}$ & $\begin{array}{c}0.734 \\
\left(0.86^{*}\right)\end{array}$ & $\begin{array}{l}-0.058 \\
\left(0.86^{*}\right)\end{array}$ \\
\hline $\begin{array}{c}\text { Tertiary } \\
\text { Education }\end{array}$ & $\begin{array}{c}0.182 \\
\left(0.04^{*}\right)\end{array}$ & $\begin{array}{c}1.722 \\
\left(0.43^{*}\right)\end{array}$ & $\begin{array}{l}-2.568 \\
\left(0.44^{*}\right)\end{array}$ & $\begin{array}{l}-2.691 \\
\left(0.43^{*}\right)\end{array}$ & $\begin{array}{c}0.257 \\
(0.03 *)\end{array}$ & $\begin{array}{c}1.201 \\
(0.01 *)\end{array}$ & $\begin{array}{c}0.761 \\
\left(0.83^{*}\right)\end{array}$ & $\begin{array}{c}0.072 \\
(0.82 *)\end{array}$ \\
\hline Physical capital & $\begin{array}{c}0.718 \\
\left(0.25^{*}\right)\end{array}$ & $\begin{array}{c}0.035 \\
\left(0.96^{*}\right)\end{array}$ & $\begin{array}{c}0.974 \\
(0.45 *)\end{array}$ & $\begin{array}{c}3.426 \\
\left(0.65^{*}\right)\end{array}$ & $\begin{array}{c}0.124 \\
(0.75 *)\end{array}$ & $\begin{array}{c}0.032 \\
\left(0.96^{*}\right)\end{array}$ & $\begin{array}{c}1.334 \\
\left(0.38^{*}\right)\end{array}$ & $\begin{array}{c}0.111 \\
\left(0.41^{*}\right)\end{array}$ \\
\hline Urban & $\begin{array}{c}0.002 \\
\left(0.96^{*}\right)\end{array}$ & $\begin{array}{c}0.015 \\
\left(0.75^{*}\right)\end{array}$ & $\begin{array}{l}-0.081 \\
(0.30 *)\end{array}$ & $\begin{array}{l}-0.054 \\
\left(0.47^{*}\right)\end{array}$ & $\begin{array}{l}-0.146 \\
\left(0.39^{*}\right)\end{array}$ & $\begin{array}{l}-0.180 \\
\left(0.51^{*}\right)\end{array}$ & $\begin{array}{l}-0.088 \\
\left(0.85^{*}\right)\end{array}$ & $\begin{array}{l}-0.005 \\
(0.65 *)\end{array}$ \\
\hline Entrepreneurship & $\begin{array}{c}3.401 \\
(0.01 *)\end{array}$ & $\begin{array}{c}3.124 \\
\left(0.03^{*}\right)\end{array}$ & $\begin{array}{c}5.477 \\
\left(0.31^{*}\right)\end{array}$ & $\begin{array}{c}1.380 \\
\left(0.74^{*}\right)\end{array}$ & $\begin{array}{c}0.933 \\
\left(0.04^{*}\right)\end{array}$ & $\begin{array}{c}2.899 \\
\left(0.03^{*}\right)\end{array}$ & $\begin{array}{c}4.392 \\
(0.42 *)\end{array}$ & $\begin{array}{c}0.648 \\
\left(0.13^{*}\right)\end{array}$ \\
\hline Intercept & $\begin{array}{c}0.475 \\
\left(0.09^{*}\right)\end{array}$ & $\begin{array}{c}0.378 \\
(0.30 *)\end{array}$ & $\begin{array}{c}0.307 \\
\left(0.58^{*}\right)\end{array}$ & $\begin{array}{l}-0.005 \\
(0.99 *)\end{array}$ & $\begin{array}{l}-0.677 \\
\left(0.01^{*}\right)\end{array}$ & $\begin{array}{l}-0.495 \\
(0.30 *)\end{array}$ & $\begin{array}{l}-0.039 \\
\left(0.96^{*}\right)\end{array}$ & $\begin{array}{l}-0.212 \\
(0.00 *)\end{array}$ \\
\hline $\begin{array}{c}\text { Number of } \\
\text { Observations }\end{array}$ & 38 & 38 & & & 38 & 38 & & \\
\hline R-squared & 0.828 & 0.675 & & & 0.501 & 0.299 & & \\
\hline $\begin{array}{l}\text { Adjusted } \\
\text { R-squared }\end{array}$ & 0.781 & 0.586 & & & 0.364 & 0.106 & & \\
\hline
\end{tabular}

Note: ${ }^{* * *}$, and ${ }^{* * *}$ indicate statistical significance at the $1 \%, 5 \%$ and $10 \%$ levels, respectively. Source: own calculations.

From Table 3, we observe that the urban population [29] had no impact on either the resistance index or the recovery (the associated probabilities $>0.05$ were 0.96 for resistance and 0.39 for recovery, respectively). In contrast, education [30], represented by tertiary education, influenced in both periods the phenomena of resistance and recovery, the influence being more important in the second period ( 0.182 for the first period and 0.257 for the second period). The physical capital, represented by the gross fixed capital formation [31,32], did not influence the phenomena of resistance and recovery (the associated probabilities were $>0.05$ of 0.25 and 0.75 , respectively).

However, the results from quantile regressions should be taken with caution due to the small sample size of our analysis.

\section{Discussion and Conclusions}

The economic recession related to the crisis of 2008-2009 has produced important changes in the economy of the Eastern European states and their regions, but the impact is different from state to state and from one region to another. Most of the studies on regional resilience have focused on the Western states, the studies on the regions of the Eastern European states being very few and focusing in particular on the overall problems of the economy.

The present study analyzes the phenomenon of regional resilience for seven Eastern European states (Bulgaria, Hungary, Croatia, Czech Republic, Romania, Slovakia and Slovenia) and their regions, compared to the EU region. The analysis was performed for two distinct periods: the period of economic downturn, in which the phenomenon of resistance manifested itself (with the best performers being Bulgaria and Slovenia), and the recovery period, which differed in the analyzed states. This period 
was smaller in Bulgaria, Czech Republic, Hungary, Romania and Slovakia, compared to Croatia and Slovenia.

Following the analysis, three major conclusions can be drawn. Firstly, agriculture, population and physical capital do not influence resilience and its two components, resistance and recovery. The second conclusion is that the manufacturing and service sectors switched places during the crisis, so that manufacturing was influential in the period of resistance while services became more important in the recovery period. Finally, we noticed that public administration and tertiary education had a positive influence on regional resilience. Public administration played its most important part in the first period, resistance to recovery, while tertiary education did the same in the recovery period.

Based on the analysis, it can be concluded that these Eastern regions have some capacity for economic resilience, more pronounced in Bulgaria and Slovenia, but weaker in other states (Czech Republic, Croatia, Hungary, Romania and Slovakia) and their regions. Separately, on the two components, the regions of Bulgaria and Slovenia show a greater resistance than the regions of the other countries, the phenomenon of the recession settling harder after one year. At the same time, for the recovery phenomenon, the situation is similar: the regions in Bulgaria, Czech Republic, Hungary, Romania and Slovakia have recovered faster (2010-2012), while those in Croatia and Slovenia have been hit much harder (2009-2014).

The limitations of the study are given by the investigation of only seven European countries during a single crisis (2008-2014). However, since previous articles only analyze one country over the same period, this study constitutes an improvement. Nevertheless, future research will require an exploration of all the Eastern European states and their regions for a longer period, if data are available.

The implications for policymakers are that the seven states should focus on determinants with a positive influence on resilience. Thus, the service sector must be developed by stimulating new economic activities, the role of public administration must be improved by increasing its role and efficiency in society and the percentage of population with tertiary education must be increased by improving the quality of education, European sizing of curricula and educational requirements.

Author Contributions: Conceptualization, F.O., M.O., D.L., G.V. and G.P.; methodology, F.O., M.O., D.L., G.V. and G.P.; formal analysis, F.O., M.O., D.L., G.V. and G.P.; investigation, F.O., M.O., D.L., G.V. and G.P.; writing-original draft preparation, F.O., M.O., D.L., G.V. and G.P. All authors have read and agreed to the published version of the manuscript.

Funding: For Florin OPREA (Faculty of Economics and Business Administration \& Centre for European StudiesAlexandru Ioan Cuza University of Iasi, Romania), this work was supported by a grant of the Ministry of Research and Innovation, CNCS-UEFISCDI, project number PN-III-P4-ID-PCCF-2016-0166, within PNCDI III, project ReGrowEU-Advancing ground-breaking research in regional growth and development theories, through a resilience approach: towards a convergent, balanced and sustainable European Union.

Acknowledgments: The authors are grateful to the constructive comments from three anonymous reviewers. We sincerely appreciate all valuable comments and suggestions of guest editor Raul Ramos, which helped us to improve the quality of the article significantly. Any errors and misinterpretations remain the responsibility of the authors.

Conflicts of Interest: The authors declare no conflicts of interest.

\section{References}

1. Martin, R.; Sunley, P.; Gardiner, B.; Tyler, P. How regions react to recessions: Resilience and the role of economic structure. Reg. Stud. 2016, 50, 561-585. [CrossRef]

2. Crescenzi, R.; Luca, D.; Milio, S. The geography of the economic crisis in Europe: National macroeconomic conditions, regional structural factors and short-term economic performance. Camb. J. Reg. Econ. Soc. 2016, 9, 13-32. [CrossRef]

3. European Spatial Planning Observation Network. Economic Crisis: Resilience of Regions; European Observation Network for Territorial Development and Cohesion (ESPON): Luxembourg, 2014.

4. Stanickova, M.; Melecký, L. Understanding of resilience in the context of regional development using composite index approach: The case of European Union NUTS-2 regions. Reg. Stud. Reg. Sci. 2018, 5, 231-254. [CrossRef] 
5. Pascariu, G.C.; Frunză, R. Eastern versus Southern Peripherality in the EU: The study from the perspective of centre-periphery model. Transform. Bus. Econ. 2011, 10, 590-611.

6. Briguglio, L.; Cordina, G.; Farrugia, N.; Vella, S. Economic vulnerability and resilience: Concepts and measurements. Oxf. Dev. Stud. 2009, 37, 229-247. [CrossRef]

7. Simmie, J.; Martin, R. The economic resilience of regions: Towards an evolutionary approach. Camb. J. Reg. Econ. Soc. 2010, 3, 27-43. [CrossRef]

8. Martin, R. Regional economic resilience, hysteresis and recessionary shocks. J. Econ. Geogr. 2012, 12, 1-32. [CrossRef]

9. Rizzi, P.; Graziano, P.; Dallara, A. A capacity approach to territorial resilience: The case of European regions. Ann. Reg. Sci. 2018, 60, 285-328. [CrossRef]

10. Christopherson, S.; Michie, J.; Tyler, P. Regional resilience: Theoretical and empirical perspectives. Camb. J. Reg. Econ. Soc. 2010, 3, 3-10. [CrossRef]

11. Vega, S.H.; Elhorst, P. Modelling regional labour market dynamics in space and time. Pap. Reg. 2014, 93, 819-841. [CrossRef]

12. Giannakis, E.; Bruggeman, A. Determinants of regional resilience to economic crisis: A European perspective. Eur. Plan. Stud. 2017. [CrossRef]

13. Capello, R.; Caragliu, A.; Fratesi, U. Spatial heterogeneity in the costs of the economic crisis in Europe: Are cities sources of regional resilience? J. Econ. Geogr. 2015, 15, 951-972. [CrossRef]

14. Pontarollo, N.; Serpieri, C. A Composite Policy Tool to Measure Territorial Resilience Capacity; Publications Office of the European Union: Luxembourg, 2018; ISBN 978-92-79-81860-8. [CrossRef]

15. OECD. OECD Regional Outlook 2011: Building Resilient Regions for Stronger Economies; OECD: Paris, France, 2011. [CrossRef]

16. Brakman, S.; Garretsen, H.; van Marrewijk, C. Regional resilience across Europe: On urbanisation and the initial impact of the great recession. Camb. J. Reg. Econ. Soc. 2015, 8, 225-240. [CrossRef]

17. Clark, J.; Huang, H.I.; Walsh, J. A typology of 'Innovation Districts': What it means for regional resilience. Camb. J. Reg. Econ. Soc. 2010, 3, 121-137. [CrossRef]

18. Fratesi, U.; Rodriguez-Pose, A. The crisis and regional employment in Europe: What role for sheltered economies? Camb. J. Reg. Econ. Soc. 2016, 9, 33-57. [CrossRef]

19. Rose, A. Defining and measuring economic resilience to disasters. Disaster Prev. Manag. Int. J. 2004, 13, 307-314. [CrossRef]

20. Navarro-Espigares, J.L.; Martín-Segura, J.A. The role of the service sector in regional economic resilience. The resilience of the global service economy. Serv. Ind. J. 2012, 32, 571-590. [CrossRef]

21. European Commission. Regional Focus-The Regional Lisbon Index. 2010. Available online: http: //ec.europa.eu/regional_policy/sources/docgener/focus/2010_03_lisbon_index.pdf (accessed on 4 May 2020).

22. Di Caro, P. Testing and explaining economic resilience with an application to Italian regions. Pap. Reg. Sci. 2015. [CrossRef]

23. Lagravinese, R. Economic crisis and rising gaps North-South: Evidence from the Italian regions. Camb. J. Reg. Econ. Soc. 2015, 8, 331-342. [CrossRef]

24. Rose, A.; Krausmann, E. An economic framework for the development of a resilience index for business recovery. Int. J. Disaster Risk Reduct. 2013, 5, 73-83. [CrossRef]

25. Charron, N.; Dijkstra, L.; Lapuente, V. Mapping the regional divide in Europe: A measure for assessing quality of government in 206 European regions. Soc. Indic. Res. 2015, 122, 315-346. [CrossRef]

26. Groot, S.P.T.; Mohlmann, J.L.; Garretsen, J.H.; de Groot, H.L.F. The crisis sensitivity of European countries and regions: Stylized facts and spatial heterogeneity. Camb. J. Reg. Econ. Soc. 2011, 4, 437-456. [CrossRef]

27. Nistotskaya, M.; Charron, N.; Lapuente, V. The wealth of regions: Quality of government and SMEs in 172 European regions. Environ. Plan. C Gov. Policy 2015, 33, 1125-1155. [CrossRef]

28. OECD. OECD G20 Policy Paper on Economic Resilience and Structural Policies; OECD: Paris, France, 2017.

29. Rios, V. What drives unemployment disparities in European regions? A dynamic spatial panel approach. Reg. Stud. 2017, 51, 1599-1611. [CrossRef]

30. Doran, J.; Fingleton, B. Employment resilience in Europe and the 2008 economic crisis: Insights from micro-level data. Reg. Stud. 2016, 50, 644-656. [CrossRef] 
31. Ezcurra, R. Unemployment volatility and regional specialization in the European Union. Reg. Stud. 2011, 45, 1121-1137. [CrossRef]

32. Clipa, R.I.; Ifrim, M. Measuring regional competitiveness. The case of Romania. Ann. Univ. Oradea Econ. Sci. 2016, 1, 103-111.

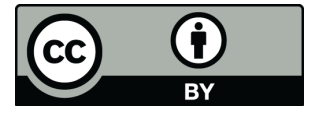

(C) 2020 by the authors. Licensee MDPI, Basel, Switzerland. This article is an open access article distributed under the terms and conditions of the Creative Commons Attribution (CC BY) license (http://creativecommons.org/licenses/by/4.0/). 